\title{
PREVENTION OF ADENOVIRAL EYE INFECTION — REVIEW
}

\author{
Janicijevic Katarina, ${ }^{1}$ Kocic Sanja, ${ }^{1}$ Radovanovic Snezana, ${ }^{1}$ Radevic Svetlana, ${ }^{1}$ \\ Vasiljevic Dragan, ${ }^{1}$ Djonovic Nela, ${ }^{1}$ Sarenac Vulovic Tatjana ${ }^{1,2}$ \\ ${ }^{1}$ Faculty of Medical Sciences, University of Kragujevac, Serbia \\ ${ }^{2}$ Clinic of Ophthalmology, Clinical Centre of Kragujevac, Serbia
}

Primljen/Received 04. 11. 2016. god.

Abstract: Epidemic viral conjunctivitis caused by adenovirus is the most common infectious conjunctivitis. The exact incidence of adenoviral conjunctivitis is still poorly known, but there are two well-defined adenoviral keratoconjunctivitis clinical syndromes: epidemic keratoconjunctivitis (EKC) and pharyngoconjunctival fever (PCF). Epidemic keratoconjunctivitis is also the most severe form and presents with watery discharge, hyperemia, chemosis and ipsilateral lymphadenopathy. Diagnosis is mainly clinical, but its etiology can be confirmed using cell cultures, antigen detection, polymerase chain reaction or immune-chromatography. Multiple treatments have been tried for this disease, but none of them seem to be completely effective. Viruses are resistant to desiccation and certain common surface disinfectants. Prevention is the most reliable and recommended strategy to control this epidemic infection. Global epidemic surveillance system definitely needs to be established to monitor and analyze the epidemic conjunctivitis in the future. There is clearly a need for the national and the military public health institutions to work together on guidelines to handle future challenges.

Key words: epidemic, adenoviral, conjunctivitis, keratitis, diagnosis, therapy, prevention.

\section{INTRODUCTION \\ PREVENTION OF ADENOVIRAL EYE INFECTION - REVIEW}

Keratoconjunctivitis is corneal and conjunctival inflammation. Epidemic viral conjunctivitis caused by adenovirus is the most common infectious conjunctivitis and a highly contagious eye disease that occurs worldwide. Cases are more frequent during warmer months. Epidemiological analysis indicated the regional and the seasonal distribution dominated in the win-
Prihvaćen/Accepted 19. 12. 2016. god.

ter and early spring. The exact incidence of adenoviral conjunctivitis is still poorly known (1).

There are two well-defined adenoviral keratoconjunctivitis clinical features: epidemic keratoconjunctivitis and pharyngoconjunctival fever, which are caused by different serotypes. Adenoviruses are highly contagious pathogens. Pathogens commonly detected in epidemic keratoconjunctivitis outbreaks are human adenovirus serotypes 8, 19, 37, etc. Epidemic keratoconjunctivitis caused by new genomic variants of adenovirus types 8,19 and 37 (2). Adenovirus serotype 8 represents the main agent of epidemic keratoconjunctivitis and outbreaks mainly occur in hospital wards. Adenoviruses' conjunctivitis is generally severe, lasting two to three weeks. Keratitis with persistent infiltrates may be observed for more than a year (2).

Keratoconjunctivitis caused by adenoviruses (epidemic keratoconjunctivitis, ICD10, B30) is very common. It can be severe and may cause significant morbidity. In the early stages of adenoviral infections, it is often difficult to differentiate the clinical presentation from other causes of red eye (3).

Incubation period is approximately 14 days. The modes of transmission are mainly through hand-eye contact, ocular secretions and contact with ophthalmic care providers and the medical instruments. Epidemic keratoconjunctivitis is also the most severe form and presents with irritative triade, mixed hyperemia, chemosis, conjunctival membranes and subconjunctival hemorrhage, corneal subepithelial infiltrates and ipsilateral lymphadenopathy. Pharyngoconjunctival fever is characterized by abrupt onset of high fever, pharyngitis, bilateral conjunctivitis and periauricular lymph node enlargement. Adenoviral infection typically starts with a unilateral foreign body sensation and then develops, within a few hours or days, into bilateral keratoconjunctivitis with marked chemosis, epiphora and 
photophobia. Because of its highly resistant properties to desiccation and highly developed escape mechanisms which protect the virus from the host's immune response, long-term problems often remain. Remnants of viral proteins often persist on the corneal surface of Bowman's layer for a long time, and may lead to the formation of subepithelial infiltrates (4).

Epidemic keratoconjunctivitis is eye infection characterized by inflammation of the conjunctiva and cornea and can result in vision loss. Visual impairment can persist for months because of subepithelial corneal infiltrates (nummular), irregular astigmatism, etc. Several complications, such as corneal erosion and conjunctival pseudomembrane, are observed in some of the cases and corneal subepithelial opacity may bring visual impairment (5).

\section{DIAGNOSES}

Diagnosis is mainly clinical, but its etiology can be confirmed using cell cultures, antigen detection, polymerase chain reaction or immunochromatography, etc (6).

Even today the diagnosis is still mainly clinical, with laboratory tests only rarely contributing. New diagnostic tests, such as the Rapid Pathogen Detector, the AdenoPlus detection kit, that are practical, rapid and expensive to use in the general practice may obviate the problems (7).

\section{THERAPEUTIC APPROACHES}

There is no actual treatment of epidemic keratoconjunctivitis and therefore preventive measures appear as essential to avoid and/or limit such outbreaks in hospital wards. Multiple treatments have been tried for this disease, but none of them seem to be completely effective. Viruses are resistant to desiccation and certain common surface disinfectants. Contagion is possible through direct contact or fomites and the virus is extremely resistant to different physical and chemical agents. Effective antiviral treatments and vaccines are not available. Antiseptics and disinfectants are extensively used in hospitals and other health care settings for a variety of topical and hard-surface applications. A wide variety of active chemical agents (biocides) are found in these products, many of which have been used for hundreds of years, including alcohols, phenols, iodine and chlorine. Most of these active agents demonstrate broad-spectrum antimicrobial activity. However, little is known about the mode of action of these agents in comparison to antibiotics (8).

Currently, no effective, cost-efficient and tolerable virustatic is available. Treatment is symptomatic and anti-inflammatory. Late scarring may be amenable to phototherapeutic keratectomy. Cyclosporin A eye drops are a good option with a low risk profile. The use of topical steroids can possibly be disadvantageous but can be discussed at all stages of the disease. As nosocomial spread of adenoviruses is relatively common, preventive measures remain the major responsibility for ophthalmologists (9).

\section{PREVENTION ASPECTS 1}

The virus is endemic in the general population, and frequently causes severe disease in immunocompromised patients, especially the pediatric patients. Prevention is the most reliable way to control this contagious infection $(10,11)$.

Disinfection of semi-critical products with alcohol $70 \%$ or in an approximate concentration can not be recommended to all health care products in an unrestricted way (12).

Isopropyl alcohol, with limited activity against adenovirus in vitro, also was being used to "disinfect" pneumo-tonometer tips between uses at six other area eye clinics polled by telephone. The results demonstrate the need for changes in the design and manufacture of equipment used in the eye clinics (13).

Epidemic keratoconjunctivitis were treated with different eye drops: cortisone, antibiotics and iodine. Iodine showed that inflammatory symptoms disappeared rapidly, corneal complications however such as superficial keratitis could not be prevented. On account of the hygienic prophylactic measures further infections could be prevented at the clinics almost completely (14).

Polymerase Chain Reaction test (PCR test) is the gold standard for the detection of human adenovirus. The same is also high costs for many clinical laboratories. The combination of homogenization and heat treatment of sensitive in-house real-time PCR provides accurate results at a price comparable price as a viral culture (15).

Employees of the Johns Hopkins Hospital with signs and symptoms of adenoviral conjunctivitis were underwent rapid diagnosis in real time PCR. Prevention of infection is a useful tool, which reduces the loss of productivity in relation to clinical diagnosis, and determines prevalence of serotype adenoviruses in working populations (16).

Hospital employees with suspected adenoviral conjunctivitis underwent evaluation and testing with real-time polymerase chain reaction. Four employees had genotypes consistent with epidemic keratoconjunctivitis. This algorithm minimizes productivity loss compared with clinical diagnosis (17).

Adenovirus was the most common virus isolated from conjunctiva $(60-70 \%)$. It is essential that a rapid 
and specific diagnosis is offered under atypical viral presentation for the institution of specific antiviral therapy and to avoid complications that can be a result of inappropriate treatment (18).

Around a million people in Japan are suffering from adenoviral conjunctivitis every year and it is recognized as one of the major pathogens of nosocomial infection. Remarkable anti adenoviral effect was observed in zalcitabin, sanilbudine, and interferon beta and anti-osteopontin peptide. Interferon beta and antiosteopontin peptide displayed anti adenoviral effects by absorption inhibition. These agents are divided into two categories: inhibitors of adenoviral replication-zalcitabin and sanilbudine; and suppressors of adenoviral infection- interferon beta and antiosteopontin peptide. It is expected that eye drops for specific treatment of adenoviral conjunctivitis are going to be available in the near future following investigation of therapeutic effect in adenoviral infected animals and clinical trials in humans (19).

Many different germicides (antiseptics and disinfectants) were selected for many study based on their current uses in health care. These results emphasize the need for proper selection of germicides for use in disinfecting noncritical surfaces and semi critical medical devices, such as applanation tonometer, in order to prevent outbreaks of epidemic keratoconjunctivitis (20).

\section{PREVENTION ASPECTS 2}

Many ophthalmic solutions, or laser therapies were not associated with infection, and all environmental cultures were negative. This outbreak emphasizes the need for implementation of routine infection control the guidelines to prevent nosocomial transmission of epidemic keratoconjunctivitis and stresses the need for appropriate disinfection of many instruments (21).

Epidemiology encompasses identification of infectious disease, vectors of transmission, containment practices and preventative measures to stop further transmission of disease can be contracted from interpersonal exposure, contact with contaminated items or iatrogenic transmission from health-care settings and providers. The interview process and patient education are method of epidemiologic assessment that acts as the format to dealing with the epidemics (22).

This review considers what is known about the mode of action and spectrum of activity of antiseptics and disinfectants. The widespread use of these products has prompted some speculation on the development of microbial resistance, in particular whether antibiotic resistance is induced by antiseptics or/and disinfectants $(23,24)$.

The evaluation of patient care practices showed that common risk factors among affected cases were measurement of ocular tension with a tonometer in the Ophthalmology Clinic (without disinfection of the tonometer between patients), contamination of work surfaces (equipment, furniture), and poor compliance of hand hygiene. Control measures adopted were cleaning, disinfection of tonometer, equipment and work surfaces, and reinforcement of hand hygiene measures. With these measures, it was possible to control the nosocomial outbreak, despite the continued outpatient care of community-acquired cases $(25,26)$.

The Goldmann applanation tonometer presents the problem of being one of the most widely used pieces of equipment in the ophthalmic clinics and a known risk factor for the transmission of epidemic keratoconjunctivitis. There are the 3 effectiveness methods of disinfection: alcohol swabs, immersion in peroxide and the use of disposable prisms. An economic evaluation is undertaken to assess the cost-effectiveness of the 3 alternatives. The analysis was undertaken from the hospital perspective and included all equipment and labor costs. The incremental cost-effective ratios from the cost-effectiveness analysis were $\$ 12,000 /$ case averted using peroxide and $\$ 61,000 /$ case averted with Tonosafe as compared with alcohol (27).

Diagnosis of viral conjunctivitis is clinical accuracy rate of less than $50 \%$. Rapid diagnostic tests are cost benefit to reduce the unnecessary use of local antibiotics. Most cases are self-curable, and the complex treatment is required in complicated cases (28).

Gottsch's study was to determine whether implementation of measures in control policies and procedures for infection can reduce number of outbreaks in epidemic keratoconjunctivitis and number nosocomial infected patients. Measures of infection control are determined in the regulations implemented in 1992 and include: management of the patient, hand washing, disinfection of instruments, distribution of medicines and personal employees. After implementation of measures there were significantly less epidemic number and affected patients of adenoviral conjunctivitis $(29,30)$.

The West Virginia Bureau for Public Health was notified by urban ophthalmology as epidemic keratoconjunctivitis occurs of casual interaction in health care organizations and in the community. The persistence of live virus on the surfaces for up to 30-35 days hampers outbreak prevention and control efforts $(31,32$, $33,34)$.

\section{CONCLUSION}

Today, deterioration of the clinical symptoms presents a new challenge for future resources. The virus is very resistant to desiccation and it is transmitted by direct contact. Immune reaction against these remnants 
will lead to the formation of subepithelial infiltrates and subconjunctival haemorrhagiae. The diagnosis is mainly clinical, with laboratory tests only rarely contributing information rapidly. Diagnosis of etiology can be confirmed using cell cultures, antigen detection, polymerase chain reaction and/or immunochromatography.

Multiple treatments have been tried for epidemic disease, but none of them seem to be completely effective. There is no other treatment than symptomatic eye drops. The major sequelae are subepithelial infiltrates, which are difficult to treat. The use of topical steroids is discussed at all stages of the disease. Randomized clinical trials have not shown any clear benefit in the acute phase from any of a variety of treatments, including steroids, calcineurin inhibitors, virostatic drugs and many disinfecting agents. In the chronic phase, cyclosporin A eye drops accelerate the regression of subepithelial infiltrates. The hygienic measures, including conscientious hand and surface disinfection, can stop the spread of the contagious disease. The first priority in the treatment of patients with definite or suspected epidemic keratoconjunctivitis is the rigorous application of hygienic measures in medical facilities.

Prevention is the most reliable and recommended strategy to control the contagious infection and the most important action of the ophthalmologists. We presented and analyzed keratoconjunctival epidemic in region of Kragujevac from September 2008 to February 2009. The most common causes of our epidemic were adenovirus, herpes virus, and rarely cytomegalovirus, occurred with higher frequency as secondary infections (serological tests confirmed mixed distribution of the cause). All outpatients activities were carried out, while hospital hygienic, sanitary, intra-, extra-hospital and therapeutic procedures were undertaken (33). Based on the authors' experience, in order to eradicate epidemics as fast as possible and achieve efficient treatment, it is recommended that the epidemic should be reported, guidelines of referent institutions be obeyed, all of which diminishes the recognizable our professional risk and our decreases mistakes.

Global epidemic surveillance system definitely needs to be established to monitor and analyze the epidemic conjunctivitis in the future. There is clearly a need for the national and the military public health institutions to work together on guidelines to handle future challenges.

\section{CONFLICT OF INTEREST}

The authors declare that there is no conflict of interest.

\section{Licensing}

This work is licensed under a Creative Commons Attribution 4.0 International (CC BY 4.0) License
Abbreviations
PCR - Polymerase Chain Reaction
EKC - epidemic keratoconjunctivitis
PCF - pharyngoconjunctival fever

\title{
Sažetak
}

\section{PREVECENCIJA ANENOVIRUSNOG KONJUNKTIVITISA - REVIJALNI RAD}

\author{
Janicijevic Katarina, ${ }^{1}$ Kocic Sanja, ${ }^{1}$ Radovanovic Snezana, ${ }^{1}$ Radevic Svetlana, ${ }^{1}$ \\ Vasiljevic Dragan, ${ }^{1}$ Djonovic Nela, ${ }^{1}$ Sarenac Vulovic Tatjana ${ }^{1,2}$ \\ ${ }^{1}$ Fakultet medicinskih nauka, Univerzitet u Kragujevcu, Srbija \\ ${ }^{2}$ Klinika za oftalmologiju, Klinički Centar Kragujevac, Srbija
}

Epidemijski virusni konjunktivitis uzrokovan adenovirusima je najčešći kontagiozni konjuktivitis. Tačna učestalost adenovirusnih konjuktivitisa još uvek je slabo poznata, ali su dobro definisane forme adenovirusnih keratokonjunktivitisa kroz dva klinička sindroma: epidemijski keratokonjunktivitis (EKK) i faringokonjunktivalna groznica (FKG). Epidemijski keratokonjunktivitis je najteži oblik i predstavljen je sa kliničkom slikom epifore, hiperemije, hemoze i ipsilateralne limfadenopatije. Dijagnoza je uglavnom klinička, dok se njegova etiologija može potvrditi pomoću ćelijske kulture, detekcije antigena, lančane reakcije polimeraze ili imunohromatografije. Pokušani su mnogi tretmani ove bolesti, ali nijedan od njih izgleda da nije bio potpuno efikasan. Virusi su otporni na sušenje i većini dezinfekcionih sredstava za tretiranje raznih površina. Prevencija je najpouzdaniji postupak i preporučuje se kao strategija za kontrolu navedene epidemije. Sistematski nadzor nad globalnim epidemijama, definitivno mora da se uspostavi, da prati i analizira epidemije virusnih konjuktivitisa $u$ budućnosti. Očigledno je da postoji jaka potreba u nacionalnim i javno-vojnim, zdravstvenim ustanovama, da zajedno rade na smernicama za upravljanje budućih izazova u ovom domenu.

Ključne reči: epidemija, adeno virusi, konjunktivitis, keratitis, dijagnostika, terapija, prevencija. 


\section{REFERENCES}

1. Zhang L, Zhao N, Sha J, Wang C, Jin X, Amer S, et al. Virology and epidemiology analyses of global adenovirus-associated conjunctivitis outbreaks, 1953-2013. Epidemiol Infect. 2016; 144(8): 1661-72.

2. Chang CH, Lin KH, Sheu MM, Huang WL, Wang HZ, Chen CW. The change of etiological agents and clinical signs of epidemic viral conjunctivitis over an 18-year period in southern Taiwan. Graefes Arch Clin Exp Ophthalmol. 2003; 241(7): 554-60.

3. Pleyer U, Birnbaum F. Adenoviral keratoconjunctivitis. Ophthalmologe. 2015; 112(5): 459-69.

4. Ghebremedhin B. Human adenovirus: Viral pathogen with increasing importance. Eur J Microbiol Immunol (Bp). 2014; 4(1): 26-33.

5. González-López JJ, Morcillo-Laiz R, MuZoz-Negrete FJ. Adenoviral keratoconjunctivitis: an update. Arch Soc Esp Oftalmol. 2013; 88(3): 108-15.

6. Renard G. Adenoviral keratoconjunctivitis. J Fr Ophtalmol. 2010; 33(8): 586-92.

7. Mochizuki K, Katada T, Ohkusu K, Kaneko H. Three cases of acute conjunctivitis caused by human adenovirus in medical workers. Kansenshogaku Zasshi. 2010; 84(4): 469-73.

8. Doyle TJ, King D, Cobb J, Miller D, Johnson B. An outbreak of epidemic keratoconjunctivitis at an outpatient ophthalmology clinic. Infect Dis Rep. 2010; 2(2): e17.

9. Bialasiewicz A, Brehler R, Draeger J, Schmitz H. Mathematical modelling of epidemics under specific regard of adenoviral keratoconjunctivitis. Eur J Med Res. 2008; 13(8): 355-65.

10. Sendra-Gutiérrez JM, Martín-Rios D, Casas I, Sáez P, Tovar A, Moreno C. An outbreak of adenovirus type 8 keratoconjunctivitis in a nursing home in Madrid. Euro Surveill. 2004; 9(3): 27-30.

11. Shiota H, Ohno S, Aoki K, Azumi A, Ishiko H, Inoue Y, et al. Guideline for the nosocomial infections of adenovirus conjunctivitis. Nippon Ganka Gakkai Zasshi. 2009; 113(1): 25-46.

12. Ribeiro MM, Neumann VA, Padoveze MC, Graziano KU. Efficacy and effectiveness of alcohol in the disinfection of semi-critical materials: a systematic review. Rev Lat Am Enfermagem. 2015; 23(4): 741-52.

13. Koo D, Bouvier B, Wesley M, Courtright P, Reingold A. Epidemic keratoconjunctivitis in a university medical center ophthalmology clinic; need for re-evaluation of the design and disinfection of instruments. Infect Control Hosp Epidemiol. 1989; 10(12): 547-52.

14. Hiti H, Hanselmayer H, Hofmann H. Experience in therapy and prophylaxis of epidemic keratoconjunctivitis (author's transl). Klin Monbl Augenheilkd. 1979; 174(3): 456-61.

15. Al-Siyabi T, Binkhamis K, Wilcox M, Wong S, Pabbaraju K, Tellier R, et al. A cost effective real-time PCR for the detection of adenovirus from viral swabs. Virol J. 2013; 10: 184.

16. Kuo IC, Espinosa C, Forman M, Valsamakis A. A polymerase chain reaction-based algorithm to detect and pre- vent transmission of adenoviral conjunctivitis in hospital employees. Am J Ophthalmol. 2016; 163: 38-44.

17. Kuo IC, Espinosa C, Forman M, Pehar M, Maragakis LL, Valsamakis A. Detection and prevalence of adenoviral conjunctivitis among hospital employees using real-time polymerase chain reaction as an infection prevention tool. Infect Control Hosp Epidemiol. 2014; 35(6): 728-31.

18. Marangon FB, Miller D, Alfonso E. Laboratory results in ocular viral diseases: implications in clinical-laboratory correlation. Arq Bras Oftalmol. 2007; 70(2): 189-94.

19. Uchio E. New medical treatment for viral conjunctivitis. Nippon Ganka Gakkai Zasshi. 2005; 109(12): 962-84.

20. Rutala WA, Peacock JE, Gergen MF, Sobsey MD, Weber DJ. Efficacy of hospital germicides against adenovirus 8, a common cause of epidemic keratoconjunctivitis in health care facilities. Antimicrob Agents Chemother. 2006; 50(4): 1419-24.

21. Clement C, Capriotti JA, Kumar M, Hobden JA, Foster TP, Bhattacharjee PS et al. Clinical and antiviral efficacy of an ophthalmic formulation of dexamethasone povidone-Iodine in a rabbit model of adenoviral keratoconjunctivitis. Invest Ophthalmol Vis Sci. 2011; 52(1): 339-44.

22. Gleavy D. The nursing role in epidemiology, risk management, and patient-public education. J Ophthalmic Nurs Technol. 1990; 9(5): 215-9.

23. McDonnell G, Russell AD. Antiseptics and disinfectants: activity, action, and resistance. Clin Microbiol Rev 2001; 14(1): 227.

24. Aoki K, Benkö M, Davison AJ, Echavarria M, Erdman DD, Harrach B, et al. Members of the Adenovirus Research Community. Toward an integrated human adenovirus designation system that utilizes molecular and serological data and serves both clinical and fundamental virology. J Virol. 2011; 85(11): 5703-4.

25. Nercelles MP, Peirano NL, Herrera OR, Rivero BP, Márquez PL. A nosocomial outbreak of epidemic keratoconjunctivitis. Rev Chilena Infectol. 2010; 27(6): 534-8.

26. Meyer-Rüsenberg B, Loderstädt U, Richard G, Kaulfers PM, Gesser C. Epidemic keratoconjunctivitis: the current situation and recommendations for prevention and treatment. Dtsch Arztebl Int. 2011; 108(27): 475-80.

27. Sehulster, L., R. Y. W. Chinn. Guidelines for environmental infection control in health-care facilities. Recommendations of CDC and the Healthcare Infection Control Practices Advisory Committee (HICPAC). Morb. Mortal. Wkly. Rep. 2003; 52: $1-44$.

28. Schrauder A, Altmann D, Laude G, Claus H, Wegner K, Köhler R, et al. Epidemic conjunctivitis in Germany, 2004. Euro Surveill. 2006; 11(7): 185-7.

29. Mema SC, MacDonald J, Wyse JP, Gonder T, Musto R, McIntyre L. Public Health adds value to an investigation of epidemic keratoconjunctivitis. Can J Ophthalmol. 2010; 45(5): 538.

30. Centers for Disease Control and Prevention (CDC). Adenovirus-associated epidemic keratoconjunctivitis outbreaks four states, 2008-2010. Morb Mortal Wkly Rep. 2013; 62(32): $637-41$. 
31. Omar Akhtar A, Singh H, Si F, Hodge WG. A systematic review and cost-effectiveness analysis of tonometer disinfection methods. Can J Ophthalmol. 2014; 49(4): 345-50.

32. Jhanji V, Chan TC, Li EY, Agarwal K, Vajpayee RB. Adenoviral keratoconjunctivitis. Surv Ophthalmol. 2015; 60(5): 435-43.

\section{Correspondence to / Autor za korespondenciju}

Katarina M. Janicijevic

Faculty of Medical Sciences, University of Kragujevac, Serbia

Svetozara Markovica 69, 34000 Kragujevac, Serbia

Tel: $+38134 / 369828$

Mob: +381642183797

E-mail: kaja.andreja@yahoo.com
33. Janićijević Petrović M, Srećković S, Petrović N, Šarenac T. Epidemijski keratokonjunktivitis. Srp Arh Celok Lek. 2011; 139(5-6): 282-5.

34. Massey J, Henry R, Minich L, Lamson DM, St George K. Notes from the field: health care-associated outbreak of epidemic keratoconjunctivitis West Virginia, 2015. Morb Mortal Wkly Rep. 2016; 65(14): 382-3. 